\title{
Peculiairities of mRNA TLR-2, TLR-4 expression of the oral cavity epithelium in children under conditions of chronic catarrhal gingivitis and diabetes mellitus
}

\author{
A. V. Kotelban ${ }^{1}$, O. I. Godovanets ${ }^{1}$, G. D. Koval ${ }^{1}$, O. M. Kamyshnyi ${ }^{2}$ \\ ${ }^{1}$ Higher State Educational Establishment “Bukovinian State Medical University”, Chernivtsi, Ukraine, ${ }^{2}$ Zaporizhzhia State Medical University, Ukraine
}

Key words:

type I diabetes

mellitus,

gingivitis, TLR.

\section{Zaporozhye}

medical journal

2017; 19 (3), 310-313

DOI:

10.14739/2310-1210

2017.3.100798

E-mail:

moroz.anastasia@

rambler.ru
TLRs in epithelium of the oral cavity can be effected as due to the dental as general somatic pathology. TLR availability in the external membrane of neutrophils, macrophages, keratocytes was found to be a starting point in triggering inflammation in the periodontal tissues ensuring molecular reception of a pathogen with further involvement of important components in the inherited immunity. These effectors possess phagocytic and killer activities, ensure a number of signals activating and directing antigen-specific response by the cells of the adaptive immune system.

The aim of the study was to study mRNA TLR-2, TLR-4 in the epithelium of the oral cavity in children with chronic catarrhal gingivitis and diabetes mellitus taking to account revealed metabolic disorders.

Materials and methods. 30 children with chronic catarrhal gingivitis and diabetes mellitus type I were included into Ist group, 30 children with chronic catarrhal gingivitis were included into the IInd group and 30 absolutely healthy children - III group. Polymerase chain reaction with reverse transcription in the regime in real time (RT-RRT) was used to analyze gene expression. Buccal epithelium was used as an object for molecular-genetic study.

Results. Content of mRNA TLR-2 (90.0755) in diabetes mellitus patients was in 5.5 times higher as compared to children with CCG - 15.1505. Expression of mRNA TLR-4 in children of I group increased in 6 times as compared to the children from II group.

Conclusion. Relative quantity of mRNA TLR-2 and TLR-4 in the epithelium of the oral cavity in children with diabetes mellitus was considerably higher than in patients without chronic inflammatory disease.
Ключові слова: цукровий Аіабет І типу,

гінгівіт, toll-like receptors.

Запорізький медичний

журнал. - 2017.

T. 19, № 3(102). -

C. $310-313$

\section{Особливості експресії мPHK TLR-2, TLR-4 епітелію ротової порожнини дітей, які хворі на хронічний катаральний гінгівіт, на тлі цукрового діабету}

\section{А. В. Котельбан, О. І. Годованець, Г. А. Коваль, О. М. Камишний}

Епітелій ротової порожнини та TLR, що в них містяться, перебувають під впливом змін при стоматологічній і загальносоматичній патології. Установлено, що початком запуску запалення у тканинах пародонта є наявність TLR у зовнішній мембрані нейтрофілів, макрофрагів, кератиноцитів, які забезпечують молекулярну рецепцію патогену з включенням надалі важливих компонентів спадкового імунітету. Ці ефектори володіють фагоцитарними та кілерними активностями, забезпечують мережу сигналів, що активують і направляють антигенспецифічну відповідь клітинами адаптивної імунної системи. Загалом TLR $€$ одним із найсильніших клітинних модуляторів.

Мета роботи - вивчення мPHК TLR-2, TLR-4 в епітелії ротової порожнини дітей, які хворі на хронічний катаральний гінгівіт, за умов цукрового діабету I типу з урахуванням наявних метаболічних порушень.

Матеріали та методи. Обстежили 30 дітей, які хворі на хронічний катаральний гінгівіт, за умов цукрового діабету I типу (I група), 30 соматично здорових дітей, які хворі на хронічний катаральний гінгівіт (II група) та 30 соматично та стоматологічно здорових дітей (III група). Для аналізу експресії генів використовували метод полімеразної ланцюгової реакції зі зворотною транскрипцією в режимі реального часу (ЗТ-ПЛР). Об'єктом для молекулярно-генетичних досліджень методом ЗТ-ПЛР був букальний епітелій.

Результати. У дітей, які хворі на цукровий діабет, вміст мPHK TLR-2 $(90,0755)$ у 5,5 раза вищий від соматично здорових дітей за умов ХКГ - 15,1505. Експресія мPHK TLR-4 в дітей I групи підвищувалася відповідно у 6 разів порівняно з дітьми II групи. Найвищі значення виявлені в дітей на тлі супутньої соматичної патології за умов тяжкого ступеня ХКГ.

Висновки. Молекулярно-генетичне дослідження відносного рівня мPHK TLR-2 та TLR-4 в епітелії ротової порожнини показало, що в дітей за умов ХКГ на тлі цукрового діабету суттєво збільшені відносні рівні мPHK TLR-2, TLR-4. Отже, дослідження мають велике значення для удосконалення методів діагностики запальних процесів у тканинах пародонта шляхом визначення стану вродженого імунітету ротової порожнини та розробки лікувально-профрілактичних програм для дітей, які хворі на цукровий діабет I типу.

Ключевые слова: сахарный диабет І типа,

гингивит, TLR.

Запорожский медицинский журнак. - 2017. -

T. 19, № 3(102). -

C. $310-313$

\section{Особенности экспрессии мPHK TLR-2, TLR-4 эпителия ротовой полости детей,} больных хроническим катаральным гингивитом, на фоне сахарного диабета

\section{А. В. Котельбан, О. И. Годованец, Г. А. Коваль, А. М. Камышный}

Эпителий ротовой полости и TLR, которые в них содержатся, находятся под влиянием изменений при стоматологической и общесоматической патологии. Установлено, что отправной точкой запуска воспаления в тканях пародонта является наличие TLR во внешней мембране нейтрофилов, макрофрагов, кератиноцитов, которые обеспечивают молекулярную рецепцию патогена с последующим включением важных компонентов наследственного иммунитета. Эти эффекторы обладают фагоцитарной и киллерной активностями, обеспечивают сеть сигналов, активирующих и направляющих 
антигенспецифический ответ клетками адаптивной иммунной системы. В целом TLR является одним из самых сильных клеточных модуляторов.

Цель работы - изучение мPHK TLR-2, TLR-4 в эпителии ротовой полости детей, больных хроническим катаральным гингивитом, на фоне сахарного диабета I типа с учётом имеющихся метаболических нарушений.

Материалы и методы. Обследовано 30 детей, больных хроническим катаральным гингивитом, при сахарном диабете I типа (I группа), 30 соматически здоровых детей, больных хроническим катаральным гингивитом (II группа), и 30 соматически и стоматологически здоровых детей (III группа). Для анализа экспрессии генов использовали метод полимеразной цепной реакции с обратной транскрипцией в режиме реального времени (ОТ-ПЦР). Объектом для молекулярно-генетических исследований методом ОТ-ПЦР был буккальный эпителий.

Результаты. У детей, больных сахарным диабетом, содержание мPHK TLR-2 $(90,0755)$ в 5,5 раза выше, чем у соматически здоровых детей в условиях ХКГ - 15,1505. Экспрессия мPHК TLR-4 у детей I группы повышалась соответственно в 6 раз по сравнению с детьми II группы. Более высокие значения выявлены у детей на фоне сопутствующей соматической патологии в условиях тяжёлой степени ХКГ.

Выводы. Молекулярно-генетическое исследование относительного уровня мPHK TLR-2 и TLR-4 в эпителии ротовой полости показало, что у детей на фоне сахарного диабета существенно увеличены относительные уровни мPHK TLR-2, TLR-4. Проведённые исследования имеют большое значение для совершенствования методов диагностики воспалительных процессов в тканях пародонта путём определения состояния врождённого иммунитета полости рта и разработки лечебно-профилактических программ для детей, больных сахарным диабетом I типа.

The system of inherited immunity is formed in the process of evolution of the vertebrate animals and realized by means of cells-effectors participating in the first line of protection against all antigenic foreign compounds. The following types of cells are contained in it: epithelial cells, macrophages, dendritic cells, granulocytes, mast cells, NK-cells etc. Pattern recognition receptors (PRRs) play an important role among the factors of inherited immunity $[1,4,7]$. Among PRRs toll-like receptors (TLRs) occupy a special position. These effectors possess phagocytic and killer activities, ensure a number of signals activating and directing antigen-specific response by the cells of the adaptive immune system. They serve as a bridge between pathogen-associated molecular structures (PAMSs) and antigen-specific cells of the adaptive immune response, and transmit the signals of specific hereditarily coded receptors in soluble mediators connected with T-and B-cells through the specific cytokine-chemokine receptors. After reaction with microbial PAMSs the majority of TLRs induce activation of nuclear factor kappa-light-chain-enhancer of activated B cells (NF$\mathrm{KB}$ ) and cytokine production, mainly by MyD88-dependent way $[2,5,6]$, stimulating more stages of inflammation and ensuring activation of different types of cells participating in maintenance and regulation of inflammation.

Epithelium of the oral cavity and TLR containing in them are under the effect of changes both in dental and general somatic pathology $[3,6]$. TLR availability in the external membrane of neutrophils, macrophages, keratocytes was found to be a starting point in triggering inflammation in the periodontal tissues ensuring molecular reception of a pathogen with further involvement of important components in the inherited immunity $[3,4,8]$. In general, TLR is one of the strongest cellular modulators.

Nowadays the study of mRNA MPHK TLR-2, TLR-4 expression of the oral epithelium in children afflicted with diabetes mellitus under conditions of chronic inflammation in the periodontal tissue becomes especially topical. Awareness of their role in pathogenesis of many diseases enables not only to prognosticate the risk of development of pathology or severity of its course, but to choose specific therapy for every category of patients.

Objective of the investigation is to study mRNATLR-2, TLR-4 in the epithelium of the oral cavity in children under conditions of chronic catarrhal gingivitis against diabetes mellitus considering metabolic disorders available.

\section{Materials and methods}

To solve the purpose we examined 12-year old children afflicted by type I diabetes mellitus ( 30 individuals) who were treated in-patiently at Endocrinology Department of the Regional Municipal Establishment "Regional Children Clinical Hospital", Chernivtsi (I group). II group (30 somatically healthy children with signs of chronic catarrhal gingivitis) and the group of comparison (30 somatically and dentally healthy children of the same age) were formed from the schoolchildren of Comprehensive Secondary School № 22 in the town of Chernivtsi.

According to the degree of severity of gingivitis among the children of I and II groups there was mild degree of severity of chronic catarrhal gingivitis found (10 and 18 children respectively), moderate degree of severity (17 and 8 children) and severe degree ( 3 and 4 children).

To analyze gene expression the method of polymerase chain reaction was applied with a reverse transcription in the regime of real time (RT-RRT). The object for molecular-genetic examinations by means of RT-RRT method was the buccal epithelium.

Isolation of total RNA was conducted using the set "Trizol RNA Prep 100" (Isogen Lab., LTD, RF). Preparation for the reactions and the reactions themselves were carried out according to the Protocol.

Statistical analysis was performed using the biostatistics methods of the licensed program Statistica 6.0 (StatSoft, USA). The mean value (M), mean error $(m)$, reliability of statistical indices $(p)$ have been taken for consideration. The data have been presented in the form of $(\mathrm{M} \pm \mathrm{m})$ and were considered reliable by the level of statistical significance of $p<0.05$.

\section{Results of investigation and discussion}

RT-RRT-analysis of the buccal epithelium showed an increased relative level of expression of mRNATLR-2, TLR-4 in children afflicted by diabetes mellitus and somatically healthy children under conditions of chronic catarrhal gingivitis (CCG) (Table 1). 
Table 1. Relative level expression of mRNA of TLR-2, TLR-4 genes of the buccal epithelium in children afflicted by DM and somatically healthy children under conditions of CCG in comparison with dentally and somatically healthy children $(\mathrm{M} \pm \mathrm{m})$

\begin{tabular}{lllll}
\hline Index & $\begin{array}{l}\text { DM under conditions } \\
\text { of CCG }\end{array}$ & $\begin{array}{l}\text { Somatically healthy } \\
\text { children } \\
\text { under conditions } \\
\text { of CCG }\end{array}$ & $\begin{array}{l}\text { Somatically } \\
\text { and dentally healthy } \\
\text { children }\end{array}$ & $p$ \\
\hline TLR-2 & $90.0755 \pm 13.4187$ & $15.1505 \pm 1.0413$ & $1 \pm 0.1579$ & $\begin{array}{l}\mathrm{P}_{1}<0.05 \\
\mathrm{P}_{2}<0.01\end{array}$ \\
& & & $\mathrm{P}_{3}<0.01$ \\
TLR-4 & $75.5568 \pm 17.3306$ & $12.1195 \pm 1.3552$ & $1 \pm 0.1421$ & $\begin{array}{l}\mathrm{P}_{1}<0.01 \\
\mathrm{P}_{2}<0.01 \\
\mathrm{P}_{3}<0.01\end{array}$ \\
\hline
\end{tabular}

$\mathbf{p}_{1}$ : the probability of difference compared with Group 1 \& Group 2;

$\mathbf{p}_{2}$ : the probability of difference compared with Group 1 \& Group 3;

$\mathbf{p}_{3}$ : the probability of difference compared with Group 2 \& Group 3.

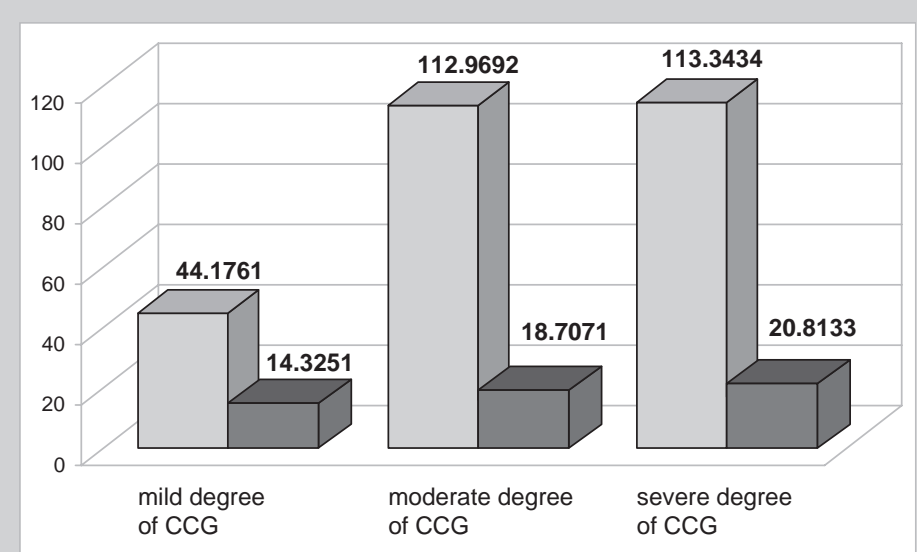

$$
\begin{array}{ll}
\square D M & \text { under conditions } \\
\text { of } C C G & \square \text { somatically healthy under conditions } \\
\text { of } C C G
\end{array}
$$

Fig. 1. Relative level of expression mRNA TLR-2 of the buccal epithelium in children afflicted by DM and somatically healthy children under conditions of CCG.

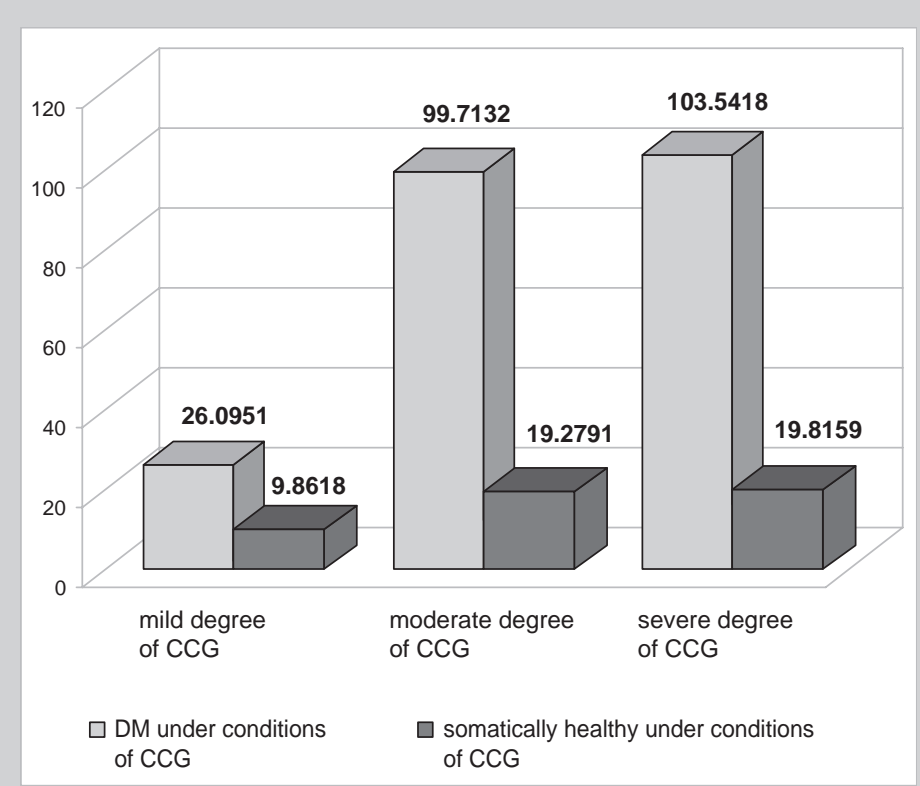

Fig. 2. Relative level of expression mRNA TLR- 4 of the buccal epithelium in children afflicted by DM and somatically healthy children under conditions of CCG.
In children afflicted by diabetes mellitus the content of mRNA TLR-2 (90.0755) is in 5.5 times higher as compared to somatically healthy children under conditions of CCG 15.1505. Expression of mRNA TLR-4 in children of I group increased 6 times as compared to the children from II group. Such results are evidenced by certain literary data and are indicative of an infectious genesis of inflammatory process in the periodontal tissues.

Expression of mRNA TLR-2 in a considerable number of children of both experimental groups was high with a tendency to increase depending on the degree of severity of CCG in children afflicted by diabetes mellitus (Fig. 1). Under conditions of mild degree of CCG in children with comorbid pathology the index was 44.1761, in somatically healthy children-14.3251. Children with moderate degree of CCG severity were characterized by the following data: 112.9692 - in I group and 18.7071 - in II group. The highest data were found in children against the ground of comorbid somatic pathology under conditions of severe degree of CCG (113.3434).

The level of mRNA expression of TLR-4 (Fig. 2) in children with the signs of mild degree of CCG against the ground of somatic pathology was 26.0951 , and among somatically healthy children it was a little lower -9.8618 . Under conditions of moderate and severe degrees of CCG expression of mRNA TLR-4 increased in children with comorbid pathology as compared to somatically healthy children, 99.7132 and 103.5418 and 19.2791 and 19.8159 respectively.

\section{Conclusions}

1. The conducted molecular-genetic study of a relative level of mRNA TLR-2 and TLR-4 in the epithelium of the oral cavity was indicative of the fact that in children against diabetes mellitus relative levels of mRNA TLR-2, TLR-4 are considerably higher.

2. The investigation conducted is of a great importance to improve the methods of diagnostics of inflammatory processes in the periodontal tissues by means of detection of the local immunity condition in the oral cavity and elaboration of therapeutic-preventive programs for children suffering from type I diabetes mellitus.

\section{References}

[1] Bairakova, A. L., Voropaeva, E. A., Afanasiev, S. S., Aleshkin, V. A., Nesvizhsky, Yu. V., Karaulov, A. V., et al. (2008) Rol' i biologicheskoe znachenie toll-podobnykh receptorov v antiinfekcionnoj rezistentnosti organizma [The role and biological significance of toll-like receptors in the anti-infectious resistance of the organism]. Vestnik RossijskojAMN, 1,45-55. [in Russian].

[2] Berezhnaya, N. M. (2013) Toll-like receptory i onkogenez [Toll-like receptors and oncogenesis]. Onkologiya, 2, 76-87. [in Russian]

[3] Ostrovska, L. J., Petrushanko, T. O., \& Kaidashev, I. P. (2009) Polimorfizm Asp299Gly gena Toll-podibnoho retseptora 4 u henezi zmin yasen u vahitnykh. [Asp299Gly gene polymorphism of Toll-like receptor 4 in the genesis of change gums in pregnancy]. Ukrainskyi stomatolohichnyi almanakh, 6, 17-21. [in Ukrainian]

[4] Simbircev, A. S. (2005) Toll-belki: specificheskie receptory nespecificheskogo immuniteta [Toll proteins: specific receptors of innate immunity]. Immunologiya, 6, 368-376. [in Russian]

[5] Sorokina, E. V. (2012) Toll-podobnye receptory i pervichnoe raspoznavanie patogena pri dermatozax infekcionnoj i neinfekcionnoj e'tiologii [Toll-like receptors and primary pathogen recognition in infectious and non-infectious cutaneous pathology]. Immunopatologiya, allergologiya, infektologiya, 2, 6-15. [in Russian]

[6] Dmitrieva, L. A., Gurevich, K. G., Tebloeva, L. M., \& Grigoryan, S. S (2012) Toll-like receptory i ikh rol' v razvitii parodontita [Toll-like receptors and their role in periodontitis]. Stomatologiya dlya vsekh, 3, 8-10. [in Russian]. 
[7] Oh, G. S., Kim, H. J., Choi, J. H., Shen, A., Kim, C. H., Kim, S. J., et al. (2011) Activation of lipopolysaccharide TLR4 signaling accelerates the ototoxic potential of cisplatin in mice. J. Immunol., 186(2), 1140-1150. doi: 10.4049/jimmunol.1002183.

[8] Terhorst, D., Kalali, B. N., Ollert, M., Ring, J., \& Mempel, M. (2010) The Role of TLR in host defenses and their relevance to dermatologic diseases. Am. J. Clin. Dermatol., 11(1), 1-10. doi: 10.2165/11311110 000000000-00000.

\section{Information about authors:}

Kotelban A. V., MD, Assistant, Department of Surgical and Pediatric Stomatology, Higher State Educational Establishment "Bukovinian State Medical University", Chernivtsi, Ukraine.

Godovanets 0. I., MD, PhD, DSci, Associate Professor, Department of Surgical and Pediatric Stomatology, Higher State Educational Establishment "Bukovinian State Medical University”, Chernivtsi, Ukraine.

Koval G. D., MD, PhD, DSci, Associate Professor, Department of Clinical Immunology, Allergology and Endocrinology, Higher State Educational Establishment "Bukovinian State Medical University", Chernivtsi, Ukraine.

Kamyshnyi O. M., MD, PhD, DSci, Professor,

Head of the Department of Microbiology, Virology and Immunology, Zaporizhzhia State Medical University, Ukraine.

\section{Відомості про авторів:}

Котельбан А. В., асистент каф. хірургічної та Аитячої стоматології, ВАНЗ “Буковинський Аержавний меАичний університет", м. Чернівці, Україна.

Годованець О. І., А-р меА. наук, Аоцент каф. хірургічної та Аитячої стоматології, ВАНЗ “Буковинський Аержавний меАичний університет", м. Чернівці, Україна.

Коваль Г. А., А-р меА. наук, Аоцент каф. клінічної імунології, алергології та ендокринології, ВАНЗ України "Буковинський Аержавний медичний університет", м. Чернівці, Україна. Камишний О. М., А-р меА. наук, професор, зав. каф. мікробіології, вірусології та імунології, Запорізький Аержавний медичний університет, Україна.

\section{Сведения об авторах:}

Котельбан А. В., ассистент каф. хирургической и детской стоматологии, ВГУЗ "Буковинский госуАарственный медицинский университет", г. Черновцы, Украина.

Годованец О. И., А-р меА. наук, Аоцент каф. хирургической и Аетской стоматологии, ВГУЗ “Буковинский государственный меАицинский университет", г. Черновцы, Украина. Коваль Г. А., А-р меА. наук, Аоцент каф. клинической иммунологии, аммергологии и энАокринологии, ВГУЗ

"Буковинский государственный меАицинский университет", г. Черновцы, Украина.

Камышный А. М., А-р меА. наук, профессор,

зав. каф. микробиологии, вирусологии и иммунологии, Запорожский государственный медицинский университет, Украина.

Конфмікт інтересів: віАсутній

Conflicts of Interest: authors have no conflict of interest to declare.

Надійшло Ао редакції / Received: 07.12.2016

Після Аоопрацювання / Revised: 15.02.2017

Прийнято Ао Аруку / Accepted: 06.03.2017 